\title{
The Indictment of God and the American Society in Countee Cullen's Poetry
}

\section{Onwu Uko Gabriel}

\begin{abstract}
The concept that God is as unjust as the society is so eloquently portrayed in Countee Cullen's poems "Yet Do I Marvel" and "Incident". Cullen accuses God of being unjust by making him a poet. The renowned poet does not exonerate his American society from the indictment based on racial hostilities and insensitivity that seemed to have permeated the milieu. This paper addresses the questions of the indictment, racial intolerance and the significance of Cullen's poetry to American literature. To achieve the objective of this study, the author adopts interpretive literary study and The Reader-Response approach to analyze the selected poems. The study reveals that Cullen's poetry like other genres lives in timeless performance, is therapeutic, is a strong vehicle for the mobilization of people and a tool for protest. The study concludes that Countee Cullen uses his poetry to indict God and American society. From the analysis of the selected poems, it is observed that poetry lives with people, is a weapon for change in any Nation and Cullen's poetry addresses the contemporary needs of a society. His accusation of God and American society is a concern and seems relevant. What matter most is equality, justice and love for humanity? All these ingredients must emanate from the heart and transcend color for any society to attain oneness.
\end{abstract}

\section{Keywords}

Indictment, racism, Marvel, Incident, African American Writers. 


\title{
The Indictment of God and The American Society in Countee Cullen's Poetry
}

\author{
Onwu Uko Gabriel
}

\section{Introduction}

Poetry addresses questions that accompany human life, nature, and the world of imagination that subsequently translate into reality. An Italian Philosopher, Giorgio Agamben asserts that when sound and sense run into each other or coincide, the poem dissolves into meaning. He draws our attention to the transparent nature of the poem and maintains that "The double intensity animating language does not die away in a final comprehension; instead, it collapses into silence, to speak, in an endless falling" (115). What a reader makes out of poetry goes on in his mind without limit. It is the duty of every critical reader to complete what is left by a poet. The contradictions, complexities, hopes and hurts encountered by the Africans in the United State before and during the era of the Harlem renaissance were glaring. People turned to poetry for answers to their numerous questions as well as for consolation. In most communities where a poet is revered as the eye of the people, his prophetic voice reveals the depth of despair in the communal soul. He reveals the promises of a future that bears the spark of hope and rebirth.

The era of the Harlem renaissance (19205-19305) in the United States ushered in a crop of talented writers and pioneers such as Claude McKay, Langston Hughes, Maya Angelou, W.E.B. Du Bois, Zora Neale Hurston, Alice Walker, Alain Locke and Countee Cullen among others. Oppression was very much glaring, racism raised her ugly head, poverty and inequality savaged the community of the Africa Americans (Blacks). In their struggles, poetry was used to resist oppression and in combination with music their deepest emotions, desires and aspirations were expressed.

The views of Oha and Uwaegbute, that "At the heart of all poetry is the appeal to the external human gifts of sympathy, wisdom, and imagination (3) vindicates Cullen's voice among his critics in black activism. He couldn't escape his African roots and blackness. Cullen questions God why He created White and Black man. The American world has passed through difficult times in its history. The scourge left by slavery, the discrimination based on colour and race has contributed to a dearth of psychological damage to victims of these social vices. African American artists tapped into their wealth 
of creativity to address those issues. They had to castigate the system, protest and speak the truth to the powers. Poetry was and has been used to conscientize the people, thus bringing a gradual change in the society.

The two poems selected for analysis in this study highlight Countee Cullen's dissatisfaction with God and the American society. Poetry remains a mirror that reflects realities in a society. Its completeness lies in its timeless performance. In "Yet do I Marvel", and 'Incident', Countee Cullen seems to accuse God of being unfair and the American society of promoting stigma as depicted in the second poem. Calling the persona a "nigger" destroys not only the boy but by extension the Black race. Therefore, Cullen's voice is universal. As cited in Ojo-Ade's "Being Black Being Human", Ngugi Wathingo is quoted to have affirmed that" the poet and politician have certainly many things in common because both used words to define and determine power, to influence the people and the destiny of the nation" (1966:71). This is a clear demonstration of Cullen's impact on the society he admonishes and chastises using the power of his pen. Countee Cullen explores the power of language in his poetry to present a series of indirect questions before God. The bitterness and trauma experienced in Baltimore could only be captioned using vivid imagery and phrases by the poet. $\mathrm{He}$ is the window through which the society is seen, studied and assessed. From the historical perspective, writers of African descent (blacks) were not recognized by the white community of scholars. In his essay “Writing, "Race', and the Difference It Makes”, Henry Louis Gates Jr. in Richter, H David text observes that scholarly works of the $18^{\text {th }}$ century had little or no place for the Blacks. He notes with dismay that European Philosophies of aesthetic theory believed that 'Beautiful books were reflections of sublime genius. Sublime genius was the province of the European'. (iv. 1896)

Blacks and other people of colour could not "write". The writers argued that "Writing" was among the fine arts and the most salient repository of "genius", the visible sign of reason itself. If (1927) writing was secondary to "reason" it maintained the function as the medium of expressing reason. Black writings were channels through which African American Authors were liberated. He opines with nostalgia that Europeans privileged writing as the principal measure of Africans' "humanity, their capacity for progress," their very pulse in the great chain of being, (1928). Harlem Renaissance opened doors to a huge discovery of talents among African Americans. Before the fertile period, American society was obsessed with the body of works coming from the white scholars only. The challenges of identity, non-acceptance and nonrecognition of Black writers were huge. The worst part was the criteria mapped out for becoming a poet in the white community. The recognized situation subjected talent to waste because of society's obnoxious laws and irrationality in accepting writers into the realm ofthe American literary circle. In his quest for answers to why God would allow injustice, discrimination and inequality to thrive in the national world, Cullen indicts God. He doesn't understand why blacks are being mocked and snubbed. The trauma suffered by the poet persona is relative and is directed towards society. His visit to Baltimore left a permanent mark/injury on him. He accuses the society of promoting 
racial tendency and deliberate refusal to curb the spread of it. Good poetry is expected to respond to human condition. Part of the human condition was the non-recognition of the body of works written by African Americans (the Blacks). He accuses God and the society for making him a poet in the midst of the quandary.

This study sets out to provide a critical perspective to Countee Cullen's poems given his indictment of God and American society. The specific objectives of the study are: (i) To ascertain the extent to which Countee Cullen indicts God and American society in his poems, and the trauma experienced by the poet persona as it affects the values of tolerance and reconciliation in the society. (ii)To validate the role of a poet, the place of poetry in society and to consolidate the assertion that poetry neither ends nor dies but lives in timeless performance. The methodology adopted by the researcher includes critical reading of the selected poems employing discursive strategies and literary theories. The Reader Response Theory is applied to interpret, review and analyze the selected poems for the study. The poems of counted Cullen are used as the primary sources of data.

\section{Review of Related Literature and Discussion}

One of the major roles of a poet is to speak truth to power. The inhumane forces that threaten peace, unity and marginalization call for collective resistance. In moments of political social and national crises, poetry is sought after and used as a collective tool for rallies and protest. Crawford,N. Chyna in her article 'Good Trouble: How Protest and Rebelliousness Have Shaped the Twenty-first century' published by The Modernist Review focuses on police brutality and racial slurs in the United States. The article likens modernism to American spirit in search of a common goal called equality. The argument credited to Gosselin is that "The Harlem Renaissance and the black and African American experience are central to American Modernism". African American Protest Poetry, from 1917 to 1968 , encompasses the traditional modernist time period... within writings of the Harlem Renaissance, there are a lot of connections to social justice and protests. Poets like Langston Hughes, Countee Cullen, and Claude McKay have poems and essays that touch on some of the social justice issues, which continue to plague the US (editorials). Concise Anthology of American Literature informs that 'Yet Do I Marvel' 'is concerned with racial identity and injustice. The poet ponders the nature of God[...] while he accepts God's wisdom in most puzzling matters of life and death, he is confounded by the contradiction of his own plight in a racist society'.(1224)

The views of Pearce juxtapose poetry and protest recalling poets of Harlem renaissance. Behind the pain in the steps of the protesters is rhythm and in their chants are rhymes. Resistance is like a heartbeat. In this article, it is argued that poetry has long been fuel for resistance. Among notable protest poems in the history of African American literature are: McKay's 'To my White Friends', 'If We Must Die', Langston Hughes' 'Let America be America Again', Amiri Bamka's' Short Speech To My Friends', Maya Angelou's 'Still I Arise' to name but a few. Cullen's 'Incident' calls out 
with fury and resentment as a protest for being labelled 'Nigger' in Baltimore. It seems to me that protest literature addresses social injustices and repression as evident in Cullen's poems. Crawford opines that 'modernist protest poetry is often didactic offering instruction in order to convert readers into social activism'.

One of the most important roles of a modernist poet is to express truth to power. It is a global struggle. To create change for the masses poets are always at the front position in the manipulation of language. In recent times the world almost came to a standstill with Black Lives matter on $6^{\text {th }}$ June, 2020. Equality, human rights and social justice evoke memories. Poetry is at its best in times of unrest, upheaval, turbulence and confusion. Protest poetry takes a central stage because it can be used to either calm the storm or fan the flames. Protest poetry delivers a strong message. Poetry has a reputation devoid of political or journalistic manipulation. Our insight into other people's struggles is sharpened by poetry. The weakness identified however, is the uncertainty if protest or poetry is enough to reposition the world. Nevertheless, our hearts and mind can be changed. The aforementioned African American poets and others have demonstrated the exceptionality of poetic genre through works. The collective voices of those poets present rebelliousness in the face of oppression. Spigelman, Willard evaluates the diverse ways in which contemporary poets view the world and turn their skills into some form of pleasure. This gives rise to aestheticism in poetry. He aestheticism that poetry uses language to create beauty. By doing so, the world becomes visible thus easily attracts ambivalent set of responses. Countee Cullen like other contemporary poets see the world through his idiosyncrasy that leads to something beautiful at the end. On the co-existence of life and literature Hixson Karyn illustrates the need of African Americans to comprehend the relationship between the Harlem Renaissance writers and their use of the sonnet form. He revealed that Countee Cullen, Gwendelyon and McKay adopted the Sonnet's self-reflective structure to express their political views. By extension, the racial question is addressed. One of the concerns of this paper is aligned to his conviction that literature brings back to life the experiences of African Americans. These experiences are necessary for future generations in their effort to resolve discrimination. His reference to Countee Cullen's adoption of European format presents the poetry style of sonnet as emanated from his classical training. The formation appealed to public approval and accommodation thus Countee Cullen presents the plight of the African Americans in his poems. Karyn's work attempts to establish an understanding between content and the traditional sonnet form anchored on the critique of protest poetry. This study, however, takes a step further from the content and form to probe the poet's indictment of both God and American society. It is stated that "the sonnet served as an effective genre to voice protest poetry by Harlem Renaissance writers" experiencing W.E.B Dubois concept of Double Consciousness (Spiegelman).

This study acknowledges the importance of protest poetry. Cullen's poetry addresses 'society's misdeeds, and the prevailing racial syndrome. Readers and listeners are engaged through the power of language. Cullen expresses his dissatisfaction with God and the American society. The speaker's bitter memory of old Baltimore in his 
poem resonates decade after decades. The memory of racism never fades. Protest poetry is timeless. Cullen's work is exceptional.

\section{African America poetry and critics of Countee Cullen}

Smethurst James reveals that Countee Cullen and Langston Hughes are progenitors of Negro poetry. These poets are among the descendants of the New Negro renaissance who came of age during the second wave of Jim Crow declaration. The scholar informs that the two poets paid some allegiance to their literary ancestor, Paul Laurence Dunbar because of his influence on them. Another interesting point made of Cullen is his relationship to Greek myth probably traced to Keats. 'In Yet Do I Marvel' the reference to Greek mythology is glaring. In the lines below, Smethurst James confirms the paradoxical nature of Cullen's poetry. He writes;

[...] one finds in Cullen's poetry the idea of a divided self, and a divided society, where such explicit categories of identity as black and white, Negro and poet, pagan and Christian, and nature and civilization coexist and yet contradict or conflict with each other. (199).

Cullen's 'Yet Do I Marvel' forces the reader to ask if dichotomy exists between blackness and God's laws or those of African Americans. In matters reasons, Cullen must have seen the marvelousness yet awful strangeness that God should force him to sing. The concluding section on Cullen presents him as a powerful poet among others in the Harlem Renaissance Black poetry.Cullen is believed to have said that if he was going to be a poet at all, he was going to be a poet and not a Negro poet. A key description of African American poetry suggests that any poetry produced about and by African descent living in the United State falls in line with the concept. It seems Cullen's approach is different from the traditional stereotype adopted by other Negro Writers. Cullen's poetry attracts both Negro and white readers. He becomes of the most influential poets during the Harlem Renaissance. He never allows the circumstances of the world around him to thwart his dream of becoming a renowned poet. Hutchinson George explains that Countee Cullen's poems dominated American literary publishing magazines between 1924 and 1930. He recalled Gerald Early's argument about the dominance and importance of Cullen's poems in the Harlem Renaissance. He added that Cullen was the most celebrated black poet in the United States of America. Hutchinson uses Countee Cullen as a case study to illustrate the development and shaping of modern black literary tradition. He asserts that Cullen's poetic identity attracts a wide audience because of the combination of racial and non-racial references (2-14).

The success of African American poetry today is not without the solid foundation laid by creators of Harlem penmanship. Dodson's beautiful article published by Clark Atlanta University creates an impression that Cullen's worth is deep-seated in American literature. He is convinced that Cullen's critics would label him as 'one of the most 
brilliant American lyric poets; that in his work he combined emotion and intellect with skill and power''.( Phylon vol. 7, N0 1 .20). He imagines what other Negroes would say about Cullen's poetry. Perhaps their confusions, hurt, agony, struggles as well as pride are well captioned by this great poet of Harlem era. Research into Harlem Renaissance figures by Kent portrays Cullen as one of the writers who combines ' cosmopolitanism', and quality education to win the attention of both White and Black scholars across the United States. Huggins maintains that Cullen avoids writing in "vernacular and his diction is never marked by freshness of usage. Poetry is a very serious business to Countee Cullen; he might be light but never funny. (213)

Cullen's question addressed to God for sending him to a difficult audience who might not listen is appropriate. A poet is in a better position to ask questions that will aid reflection. It is not the intention of this paper to discuss faith or religious theme here but it might not be out of place to ask if God sometimes allows injustice, hate and discrimination to thrive in human life and history. Cullen's accusation of God and Society for misdemeanor

\section{Critical Discussion}

It appears that rule- keeping is important to the poet. His adherence to this fixed poetic form is a trade mark ascribed to this Harlem Renaissance scholar. "Yet Do I Marvel" was composed and published in Cullen's anthology "Colour" in 1925.It is foregrounded on racial injustice and identity. It is set in the middle of Harlem Renaissance. The first octave (eight lines) presents the speaker's tension and gradually have them resolved in the last couplet. Cullen's admiration for Elizabethan's style of sonnet must have influenced his writing so much as evident in "Yet Do I Marvel". Cullen is black and he is a poet (the dilemma surrounding his two identities).He laments and marvels at the same time. Refer to the last couplet. It's clear that the speaker is haunted and upset by racism. Language use is at its best and worst states as demonstrated in Cullen's "Incident" recalling the trauma and permanent damage a word could cause the persona is harrowing. If all the poet could remember from the month of May to December is that ' $\mathrm{N}$ ' word, poetry, and language are inseparable. That racial epithet alone is a canon (a detonated explosive).Readers of "Incident', are curious at the desecration of youthful innocence. Is society not sensitive to the needs of the people especially the Blacks?

Countee Cullen structures his poem to show how important the last two lines of stanzas three are to the speaker. From the beginning of his trip in Baltimore he expresses his joy and excitement and until that moment his entire world is shattered. He pulls out a surprise by stating that of all the things that happen, the speaker only remembers that scenario where he experiences a terrible gesture of unkindness from the white boy. His initial positive experience is marred by this negative remark. His smile is rebuffed and met with an awful response. What a lasting impact on the speaker and indeed other victims of racial abuse. It is assumed that the little boy is ingenious but to what extent the 
society inculcates right maxims and tolerance calls for Cullen's indictment. The researcher is of the opinion that children are what the society prepares them to be. Rarely would good training produce bad results. Good upbringing attracts good values and love devoid of discrimination. Such is not the case depicted in Cullen's "Incident".

In this paper, it is argued that poetry is an important genre in the affairs of mankind, and the functions it performs in the society. It mentions some African American talented writers of Harlem and recognizes Countee Cullen's exceptional traditional formal approach to the struggles of the African Americans with his poetic form. The similarity with the western literary canons and scholarly style makes his poetry the best work. The objectives mapped out for this study include: the examination of trauma experienced by the poet, the validation of the role of poet, the consolidation of the assertion that poetry lives forever and the analysis of the extent to which Cullen accuses God and American society these objectives form the research questions in chapter one. Next is the significance this study sets out to achieve. The need to appreciate poetic language, the implication of wrong use of language, application of Reader Response approach by scholars and creative dissemination of literary knowledge in educational environment.

This paper investigated the extent to which Countee Cullen accuses God and American society of the bad system in the events of being unjust. Cullen questions whether God is racial, cruel yet kind for making him a poet black. This in Cullen's thinking, God was callous, reckless and cruel. He marvels at God's recklessness in his poem "Yet Do I Marvel". Singing to a hostile choir is a sheer display of injustice.

From the array of scholarly works/resources consulted, the analysis of the selected poems using the Reader-Response Theory and the assessment of some basic poetic elements the topic is justified. In "Yet Do I Marvel", Countee Cullen presents a speaker in dire dilemma based on the then discriminating norm of not being appreciated or recognized because he is black. Who would read or accept his poetic talent (gift). How would being a black and poet go together? In the then Harlem Renaissance, the fundamental topic was becoming a black artist. Cullen's sonnet reveals on one hand, the relationship between God and mankind. The speaker acknowledges God's goodness, allknowing attribute such that He could explain everything if he chooses to. However, the paradox in Cullen's lines pitches God as being cruel at the same time. This is because He (God) allows injustice, inequality to permeate the beautiful world He has created. Again the speaker does not understand why mankind would die if God created him in His image and likeness. In the analysis, this study observes that the allusions made to the Greek mythology (Tantalus and Sisyphus) underscores the punishment meted out for wrong doing. These two titans are made to face consequences for falling off the track. Similarly, mankind is destined to suffer some consequences when he disobeys God or errs. The poet describes God's ways as being inscrutable, unfathomable, meaning that humans are unable to understand them. God's ways are beyond human comprehension. We can attempt to memorize all the orthodox doctrine contained in catechism but we will never be able to comprehend the mind of God. The human race consistently struggles 
with all the questions we would love God to address. These indirect questions posed in the poem portray God's reasons and purposes for everything that happens. It is in his quest for answers, the poet indicts God. The last couplet:

"Yet Do I Marvel at this curious thing

to make a poet black, and bid him sing",

ushers in a shift in the rhythm and meaning. The poet is baffled about why God should make him a poet and ask him to sing to the hostile group of people. What a selfconscious question! Countee Cullen is in awe of this interesting (curious) thing that God would insist he writes poetry when the Western society never recognized the black poet. The community at that time gave the impression that poets were only whites. "Yet Do I marvel" and "Incident" are the most powerful and recognized works from Countee Cullen. It is a marvel that the speaker, a black could be compelled to sing(write poetry).From the research, Cullen's sonnet is a quintessential poetic form that expresses the speaker's hurt, concern, difficulty and curiosity. His double role (duality) of being a poet and bid to sing and being black is symbolic. Cullen's anger that God puts him in a difficult situation transforms into something he could marvel at. Cullen celebrates the joy of being a poet. He has been put in a position to communicate his multiplicities through writing. Nothing could be more fulfilling than having his voice recognized through poetry and the perfection he has achieved, thus a formal reception/readability of his works. Both black and white communities read him. He overcomes his insecurity as a poet.

On "Incident", this research has confirmed that Cullen through the speaker protests against the portrayal of Blacks as a lesser race. The power of language exhibited is epitomized in that one word racial comment. That word alone has a huge negative effect capable of destroying a person for life. African Americans suffered in the hands of the Culture of white main stream. Cullen's poetry offers some respite to the Black populace and a political protest tool before the whites. Cullen no doubt represents the educated black populace that occupy the same position as the white intellectuals. To Cullen it is not all about being a black but being a poet is a significant achievement in the burgeoning era of Harlem Renaissance. "Incident" speaks to many departments and ministries about the racial intolerance black minorities encounter in America.

The hope, excitement and glamour envisaged by this eight year old boy are dashed as a result of his encounter in the bus. The society's failure to rid her system of bitter divisiveness, injustice and hate replaces youthful innocence symbolized by the white boy that used ' $N$ ' word on him. The psychological damage could neither be quantified nor annihilated by time or history. Cullen wants the world to rise up to the challenge and address racial intolerance. Based on the analysis of 'Incident', Cullen accuses American society of being responsible for her failure to inculcate the values of tolerance, love without discrimination and mutual co-existence between the whites and the blacks. This extends beyond old Baltimore and is not generation tied. The little child has been raised in the society or culture that teaches or promotes racism, without fully 
comprehending the implication of this vice. Did the little boy hear that word from an adult? Did he understand the meaning of it? Upbringing is very crucial and has relative implications in the lives of the young ones. That the poet plays an important role in a society harnesses the power of language to question, reprimand, teach, entertain or challenge institutions on certain realities in the prevailing political and social terrains. From the findings, Cullen indicts God and American society using his poetic skills and power to communicate with the people. He distinguishes himself among other African American Harlem Renaissance scholars. In his quest to understand who he is and the purpose of his existence he becomes a poet and directs his questions to God.

Countee Cullen lent his voice to other African American writers of Harlem era who challenged obnoxious racial stereotypes. However, in his sonnet, Countee Cullen looked beyond mere racial perception. He did not attempt to incite the spirit of revolution but the joy of being counted among the poets of the era irrespective of his dark body points to the purpose of God's creation. Perry admits that Cullen did not completely win this battle, his poem "Yet Do I Marvel" is one of his finest works. She puts it thus:

[...] his finest poetry has always evoked the image of a man devoted to the written and spoken word, a man who could make language sing for him when he wrote with all the fire of his youthful spirit.', (48)

She extols Cullen's traits and fight against racial consciousness as depicted in the poem “ Incident". In her analysis, Cullen is a 'sensitive man'. (48) If the human mind is inept or incompetent in judging God's action, these two lines from his poem are worth noting.

'Yet do I marvel at this curious thing:

To make a poet black, and bid him sing!'

They provide response to his puzzle. The fact that he is being made a black poet and placed among white dominated society that suppressed the blacks is intimidating and prophetic. Of what relevance is the prophetic voice of a poet if he doesn't use poetry to transmit information to the people and instruct them? Keep in mind that the poet found himself in the midst of audience that was considered recalcitrant or intractable. How would they receive his message not denying that it was an era of absolute suffering? If life was harsh, his choice of words would equally be harsh.

How else would he speak to his audience? Cullen wondered If God was good, why He would allow injustice and distress to permeate American society. It's very hard to turn deaf ears to the plight, struggle, and endless labour for little or no reward, segregation, hate, violence and human misery. America of today is just recovering from the massive protests and violence that greeted her country in the wake of the gruesome murder of African American George Floyd attributed to racial intention. What else does the world need than the voice of a prophet and poet to condemn this act in vivid terms? Would I be so quick to cast aspersion on anyone who questionsthe goodness of God in 
our modern world where good and evil co-exist?

Shucard explains that Cullen is "being tortured in a White millieu"' as evident in the poem " Incident'". The little boy's action of sticking out his tongue and calling the singer 'Nigger"' typifies it. On "'Yet Do I Marvel", he informs that "' the final couplet suggests " an infinity of irony and bitterness, and pathos and tragedy, coming as it does after an assertion of Cullen's faith, notwithstanding sundry other horrid mysteries (25). I am equally left in a paradoxical state trying to unravel why God would allow so much atrocity, greed, violence and hate to exist when the world should be celebrating or singing His kindness. Cullen's poem speaks to the contemporary society and provides a resource material for literary debate.

\section{Conclusion}

This study analyzes Countee Cullen's indictment of God and American society in his poetry. It further explores the psychological effect of derogatory utterance on racial ground as experienced by the speaker. The Reader Response Theory adopted for this study coupled with Agamben's idea that there is no end to poem concretize the search for deeper understanding of poetry. This study encourages literary scholars to embrace the silence that follows each poem. By doing so the deeper meaning beyond the poet's opinion can be judiciously established. A journey into the persona's psyche renders the effectiveness of the message beyond literal meaning.Race relations in America and other parts of the world is a huge threat to peaceful co-existent. It is believed that scholars in literary field will find this document helpful and use it as a tool for promoting humanity and love devoid of colour, race or religion.

The study has shown that people turn to poetry for answers to their numerous questions. In addition, poetry is used to inspire, praise, correct and unite people. It is expected that poetry rendition be institutionalized and performed at presidential inaugurations, international gatherings, graduation, festivals, and important occasions to bring history or culture of the people to life. Educational institutions and curriculum implementation groups should promote poetry appreciation by organizing periodic competitions in poetry writing and creativity among learners and instructors. In medical field poetry should be used as therapeutic tool during grief, epidemic, War/conflict, lack of hope and sadness. The healing power of poetry is out of this world.

\section{Implications and Recommendations for further studies}

The findings suggest that similar approach to poetry analysis be extended to female poets of African American decent. This research has not addressed the relationship between Countee Cullen and his friend/flat mate Eric Warlond to whom incident is written. What could possibly be the relationship between this poem, the poet and the personality involved? This study dwells so much on African American poetry with little reference to African poetry. In view of this, it is recommended that a critical reading and analysis of works by African poets about Africans and their continent be rigorously carried out to test the validity or relevance of their works to the contemporary 
world. Virtual learning has come to stay. It is observed that most learners hardly spend an hour without interacting with their electronic gadgets. With the evolution of e-book, pdf or other format, poetry recitation, reading and competition can be organized to promote reading culture among people and groups of diverse cultures. This study strongly recommends it.

\section{Works Cited}

Abadurin, Femi. Blackness: Culture, Ideology and Discourse. Dokun Publising House, 2008.

Abrams, M. H. A Glossary of Literary Terms. $8^{\text {th }}$ Edition. Thomas Wadsworth,2005. print

Abrams, Meyer H. A Glossary of Literary Terms ( $7^{\text {th }}$ Ed).Massachusetts: Heince, 1991. . 'Poetic forms and literary terminology' in The Norton Anthology of English Literature. $7^{\text {th }}$ Edition vol. 1. New York: Norton, 2000. 2944-61

Agamben, Giorgio. The End of The Poem: Studies in Poetics. E-Book. Standford University Press, 1996

Altenbend, Lynn. Handbook for the Study of Poetry. Chicago, 1989.

Amateshe, Kisa.' The Social Function of Poetry in Underdeveloped Society: An East African Experience" Nairobi. M.A Thesis, University of Nairobi, 1979.

Anderson, Mary. Reader-Response Theories and Life Narratives, Integrated Studies Project submitted to Dr Carolyn Redl in Partial fulfillment of the

Requirements for the Degree of Master of Arts-Integrated Studies Athabasca, Athabasca, Alberta June 2012.

Arp, R. Thomas and Johnson, Greg. Perrine's Literature, Structure, Sound and Sense. $9^{\text {th }}$ Edition. Thomson Wadsworth, 2006.

Bader, Philip. African-American Writers. E-Book. Facts on File, 2004.

Baker, A. Houston. Modernism and the Harlem Renaissance. University of Chicago Press, 1987.

Barthes, Roland. The Pleasure of the Text. Hill and Wang, 1975. Print

Baym, Nina et al. American Literature. Norton, 1998.

Bennett, Sandra. Identifying Themes and Poetic Devices in Selected Poems. University f Uta, 1972. 16. Print

Bernie ollila and Joe Jantas. The Definition of Poetry. December 15, 2006.

Bloom, Harold. African American Poets: Volume 1 New Edition, E-book. Info Base Publishing,2009.

Camus Albert: The Myth of Sisyphus and Other Essays. Translated from the French by Justin O'Brien.E-Book. 1955.

Crawford, N. Chyna. 'Good trouble: How Protest and rebelliousness Have Shaped the Twenty-first Century' in The Modernist Review. Elizabeth City State University, $\quad 9^{\text {th }} \quad$ November, 2020 https://modernistreviewcouk.wordpress.com/2020/11/09/good-trouble/ 
assessed on $25^{\text {th }}$ may, 2021

Culler, Johnathan. Literary Theory: A very Short Introduction. E-Book. Oxford University Press, 1997.

Dodson, Owen.' Countee Cullen'” (1903-1946). Phylon vol 7, N0 1(1st Qtr, 1946), pp19-20. Print

Edgar, V. Roberts and Henry E. Jacobs. Literature, An Introduction to Reading and Writing. New edition. Pearson Prentice Hall, 2007. print

Franklin, J H. and Moss, A. From Slavery to Freedom. $7^{\text {th }}$ edition. New York: McGraw-Hill, 1994.

Ferguson, Blanche E. Countee Cullen and the Negro Renaissance. Dodd, Mead and Co., 1966.

Gates, Louis, Henry, Jr. and Mc Kay, Y Nellie. The Norton Anthology. Norton and Company, 1997.

Gates, Louis Henry. "Writing, "'Race, and the Difference it Makes' in Richter, H David.

The Critical Tradition Classics Texts and Contemporary Tradition $2^{\text {nd }}$ Edition. WileyBlackwell, 2007. Print

Grudzina, Douglas. Introduction to Literary Theory. Prestwick house, Inc, 2010.

Heidegger, Martin. Poetry, Language, Thought. Translated by Albert Hofstadter. Harper and row Publishers, 1971.

Hirsch, Edward. A poet's Glossary. E-Book. Houghton Mifflin Harcourt, 2014.

Hornby, Albert Sydney. Oxford Advanced Learners Dictionary. Johnathan Crowder (Ed). Oxford: UP, 1995.

Huggins, Irvin Nathan. Harlem Renaissance. Oxford University press, 1973. Print

Hunt, Sanford B. ' The Negro as a Soldier.' Jstor, vol.7, N0 24 Jan.1869, pp 40-54. https:// www.jstor.org

Hutchinson, George. ' Representing African American Literature: Or, Tradition against the Individual Talent. University of Michingan, Press,

Karyn L. Hixson. Questions on Life and Literature: the Sonnets of Claude Mckay, Countee Cullen, and Gwendolyn Brooks. A Thesis Presented to the Faculty of the English department, University of Nebruska. Pro Quo LLC, 2017.

Killam, Douglas, and Rowe, Ruth. The Companion to African Literature. Indiana university Press, 2000.

Kent, George. Blackness and the Adventure of Western Culture. Third World Press, 1972. Print

Mambrol, Nasrullah.' 'key Theories of Mikhail Bakhtin', Literary Theory and Criticism. Literariness Scholarly Articles, January, 2018. https:// www.literariness.org/2018/01. accessed $9^{\text {th }}$ June, 2021.

McKay, Claude. Harlem Shadows. New York: Harcourt Brace, 1922. Print

Mcmahan, Elizabeth Day X Susars and Funk, Robert. Literature and the Writing Process. Fifth Edition. Prentice- hall Inc Print, 1999.

Meyer, Michael. The Compact Bedford Introduction to Literature. $8^{\text {th }}$ edition. Bedford/st 
Martins 2009. Print

Miall, S. David.' Reader-Response Theory" in Richer, H. David. A Companion to Literary Theory.An Anthology. $3^{\text {rd }}$ edition.E-Book. Wiley Blackwell, 2018.

Michael, George et al. Concise Anthology of American Literature. $4^{\text {th }}$ Edition. Prentice Hall, 1998. Print

Oha, C. Anthony and Uwaegbute, A. Charles. All About Literature. A Guide to Literary Terms in all Genres. Palmkraft Books, 2010

Pearce, lilly. 'The poetry of protest', in The Michingan daily. June $18^{\text {th }}, 2020$ https://www.michigandaily.com/arts/poetry-protests/assessed April $6^{\text {th }}, 2021$

Perry, Margaret. A Bio-bibliography of Countee P. Cullen 1903-1946.Greenwood Publishing Group, 1971.

Reddings ,J. Saunders. To Make a poet Black. Cornell university press, 1988

Rivkin, Julie and Ryan, Michael. Literary Theory: An Anthology. $2^{\text {nd }}$ edition. E-Book .Blackwell, 1998.

Rilke, Rainer maria. Letters To A Young Poet. W.W. Norton \& Company, 2004. Print Sarte, Jean Paul. What is Literature. Harvard University Press, 1988.

Schmidt, z. J, Crockett, L and Bogarad, R. C. Legacies.Fiction, Poetry, Drama. Fourth edition. Wadsworth Cengage Larning Print, 2009.

Scholes, Robert et al.Elements of literature.Fiction, Poetry, Drama. Oxford University Press, 2010.

Shucard, Alan. ' The poetry of Countee P. Cullen'” Dissertation'. The University of Arizona, 1971. Accessed 14/06/2021.

Smethrust, James" Lyric Stars: Countee Cullen and Langston Hughes" in Bloom, Harold. African American Poets. Vol 1 New Edition, e-Book. Info Base Publishing, 2009. 194-207 ' 'Lyric Stars: Countee Cullen and Langston Hughes" Cambridge University Press, 2007 https://www.cambridge.org/core/books/cambridgecompanion-to-the-harlem-renaissance/lyric-stars assessed May, 2021

Smith, Robert A. ' The Poetry of Countee Cullen,' Phylon, XI (Third Quarter 1950), 216-221.

Spiegelman, Willard. How Poets See the World: The Art of Description in Contemporary Poetry. E-Book. Oxford University Press, 2005.

Toomer, Jean. Cane. Liveright Publishing Corporation, 1975.

Venturino, J. Steven. The Complete Idiot's Guide to Literary theory and criticism. Alpha, 2013

Widdowson Peter and Raman Selden. A Reader's Guide to Contemporary Literary Theory. The University Press of Kentucky, 1993.

Willis, Jim. A to Z of World Religions, Places, Prophets, Saints and Seers. Jaico Publishing House, 2007

Wolfreys, J et al. Key Concepts in Literary Theory . $2^{\text {nd }}$ edition .e-Book .Edinburgh University Press, 2006.

Woodruff, Betram L. ' The Poetic Philosophy of Countee Cullen'. Phylon. 1 (Third 
Quarter 1940), 213-223.

\section{The Author}

\section{Onwu Uko Gabriel}

Department of English and Literary Studies,

Faculty of Humanities, School of Postgraduate Studies,

Veritas University, Abuja, Nigeria.

Email: gabeforu@gmail.com

\section{The Article}

Date sent: 25/05/2021

Date revised: 11/07/2021

Date Accepted: 15/07/2021 